\title{
Ecological factors drive differentiation in wolves from British Columbia
}

\author{
Violeta Muñoz-Fuentes ${ }^{1}$, Chris T. Darimont ${ }^{2,3}$, Robert K. Wayne ${ }^{4}$,
} Paul C. Paquet ${ }^{5}$ and Jennifer A. Leonard ${ }^{1,6}$

${ }^{1}$ Department of Evolutionary Biology, Uppsala University, Uppsala, Sweden, ${ }^{2}$ Department of Biology, University of Victoria, Victoria, BC, Canada, ${ }^{3}$ Raincoast Conservation Foundation, Denny Island, BC, Canada, ${ }^{4}$ Department of Ecology and Evolutionary Biology, University of California, Los Angeles, CA, USA, ${ }^{5}$ Faculty of Environmental Design, University of Calgary, Calgary, AB, Canada and ${ }^{6}$ Center for Conservation \& Evolutionary Genetics, National Zoological Park, Smithsonian Institution, Washington, DC, USA
*Correspondence: Violeta Muñoz-Fuentes, Department of Evolutionary Biology, Uppsala University, SE-752 36 Uppsala, Sweden.

E-mail: violeta.munoz@ebc.uu.se

\section{ABSTRACT}

Aim Limited population structure is predicted for vagile, generalist species, such as the grey wolf (Canis lupus L.). Our aims were to study how genetic variability of grey wolves was distributed in an area comprising different habitats that lay within the potential dispersal range of an individual and to make inferences about the impact of ecology on population structure.

Location British Columbia, Canada - which is characterized by a continuum of biogeoclimatic zones across which grey wolves are distributed - and adjacent areas in both Canada and Alaska, United States.

Methods We obtained mitochondrial DNA control region sequences from grey wolves from across the province and integrated our genetic results with data on phenotype, behaviour and ecology (distance, habitat and prey composition). We also compared the genetic diversity and differentiation of British Columbia grey wolves with those of other North American wolf populations.

Results We found strong genetic differentiation between adjacent populations of grey wolves from coastal and inland British Columbia. We show that the most likely factor explaining this differentiation is habitat discontinuity between the coastal and interior regions of British Columbia, as opposed to geographic distance or physical barriers to dispersal. We hypothesize that dispersing grey wolves select habitats similar to the one in which they were reared, and that this differentiation is maintained largely through behavioural mechanisms.

Main conclusions The identification of strong genetic structure on a scale within the dispersing capabilities of an individual suggests that ecological factors are driving wolf differentiation in British Columbia. Coastal wolves are highly distinct and representative of a unique ecosystem, whereas inland British Columbia grey wolves are more similar to adjacent populations of wolves located in Alaska, Alberta and Northwest Territories. Given their unique ecological, morphological, behavioural and genetic characteristics, grey wolves of coastal British Columbia should be considered an Evolutionary Significant Unit (ESU) and, consequently, warrant special conservation status. If ecology can drive differentiation in a highly mobile generalist such as the grey wolf, ecology probably drives differentiation in many other species as well.

\section{Keywords}

Canis lupus, conservation biogeography, ESU, faecal DNA, GPS, landscape genetics, mitochondrial DNA, museum specimens, phylogeography, wolf.

\section{INTRODUCTION}

Phylogeographic structure is a consequence of limited dispersal within the range of a species. Phylogeographic patterns may reflect isolation by distance, the presence of a barrier to dispersal (such as a geological feature or unsuitable habitat), historical events or a combination of these factors (Avise et al., 1987). Environmental and ecological variables (Doebeli \& 
Dieckmann, 2003; Nosil et al., 2005; Funk et al., 2006) and social interactions (Bolnick et al., 2003) may also contribute to shaping population structure. A geographic range that includes a variety of habitats may result in individuals that are adapted to specific environmental and/or ecological factors (e.g. Hoekstra et al., 2005). Adaptation, in turn, can cause some degree of isolation if individuals have a higher probability of survival where they were born or reared (Nosil et al., 2005). Differential fitness can lead to a reduction in effective migration between habitats and generate genetic differentiation and population structure. Phylogeographic structure generated by natural (non-anthropomorphic) causes has been proposed to be of high conservation importance, as these may be the units upon which evolution acts, and thus may even occasionally represent incipient species (Moritz, 1994). To highlight the importance of these subspecific units, the term Evolutionary Significant Unit (ESU) has been coined (Ryder, 1986). Recently, the definition of ESU has been refined to highlight the importance that ecology and local adaptation play in evolution (Crandall et al., 2000; Fraser \& Bernatchez, 2001). Identifying ESUs is therefore of high importance both for understanding the evolutionary past of a species and for ensuring its future.

Many large mammals have high dispersal capabilities and are distributed across a variety of habitats. An emerging literature shows that genetic differentiation in such mammals may be associated with ecological differences, and not solely with geographical distance. Examples include the arctic fox (Alopex lagopus; Dalén et al., 2005; but see Carmichael et al., 2007), cougar (Puma concolor; McRae et al., 2005), coyote (Canis latrans; Sacks et al., 2004), and lynx (Lynx lynx and L. canadensis; Rueness et al., 2003a,b). Perhaps the most wellknown example of divergent behaviour associated with ecological differences resulting in genetic structure is that between sympatric resident (fish-eating) and transient (marine mammal-eating) killer whales (Orcinus orca; Hoelzel et al., 1998). Quantifying the degree to which habitat drives genetic differentiation is important. If habitat specialization is a major factor driving and/or maintaining divergence, then in the absence of specific data it should be assumed that populations in different habitats are genetically differentiated, implying that when a specific habitat is threatened, a unique population, differentiated from populations of the same species in adjacent areas, is also threatened.

Grey wolves (Canis lupus L.) are highly mobile carnivores that often disperse more than $100 \mathrm{~km}$ before breeding (Fritts, 1983; Merrill \& Mech, 2000; Linnell et al., 2005). Geological features that may be barriers to some species, such as mountain ranges, probably pose little obstacle to wolf movement, and may even act as corridors (Forbes \& Boyd, 1996). In addition to their vagility, grey wolves are ecosystem generalists, occupying a wide variety of habitats. In North America, they live in habitats as diverse as arctic tundra, boreal forests, plains, mountains, deserts and temperate rain forests. Because of these characteristics, little phylogeographic structure is expected in wolves. Indeed, early phylogeographic studies of world-wide and North American grey wolves supported this prediction, showing no large-scale structure within Eurasia or America (Lehman et al., 1991; Wayne et al., 1992; Vilà et al., 1999). Studies employing more detailed sampling, however, have suggested that there may be genetic structure in grey wolf populations (Carmichael et al., 2001, 2007; Sharma et al., 2003; Geffen et al., 2004; Pilot et al., 2006; Musiani et al., 2007). Geffen et al. (2004) reanalysed some previous studies on grey wolves in North America and identified a pattern of isolation associated with habitat and climate. On a finer scale, prey specialization may drive population structure in grey wolves from Northwest Territories, Canada (Musiani et al., 2007). Similarly, ecological factors such as prey distribution, habitat and climate were found to be correlated with population genetic differentiation in grey wolves of eastern Europe (Pilot et al., 2006).

Coastal British Columbia wolves occupy a narrow region that includes mainland coast and near-shore island habitats covered by temperate rain forest that extend from Vancouver Island in the south to the Alexander Archipelago of south-east Alaska in the north (Fig. 1). Although urgency has been expressed in responding to imminent threats to biodiversity in this ecosystem, a paucity of scientific information exists to support the evolutionary importance of the region (Cook et al., 2001, 2006; Darimont \& Paquet, 2002; Paquet et al., 2004-2005). Recently, a study of south-east Alaskan wolves identified genetic divergence between interior and southeastern Alaskan coastal wolves (Weckworth et al., 2005). This highlights the need to study the wolves of adjacent British Columbia, as the coastal rain forest of south-east Alaska extends south through British Columbia.

The wolves of British Columbia, Canada, provide a good system in which to evaluate the effects of distance and habitat variation on population genetic structure because they are distributed across very different habitats on a scale within the dispersal distance of an individual (Fig. 1 and Table 1). An ecological discontinuity exists between interior and coastal regions, to the east and west of the Coast Mountain Range, respectively. The interior plateau areas are dry, with a continental climate (warm in summer, cold in winter). Eight species of ungulates, which vary in their distribution, are available as prey to inland wolves (Cowan \& Guiguet, 1975; Nagorsen, 1990; Shackleton, 1999) (Table 1). In contrast, the coastal region is defined by a low-elevation rain forest with a temperate climate (mild year-long). Only one ungulate species is distributed throughout the coast, the black-tailed deer (Odocoileus hemionus; Cowan \& Guiguet, 1975; Nagorsen, 1990; Shackleton, 1999). This deer and marine resources, such as marine mammals and seasonally spawning salmon, constitute most of the diet of coastal wolves (Darimont et al., 2004, 2007, 2008). This variability in habitat exists over geographic distances at the scale of wolves' known dispersal ranges in western North America. Consequently, an individual could potentially encounter both coastal and inland habitats in the course of its natural dispersal. 



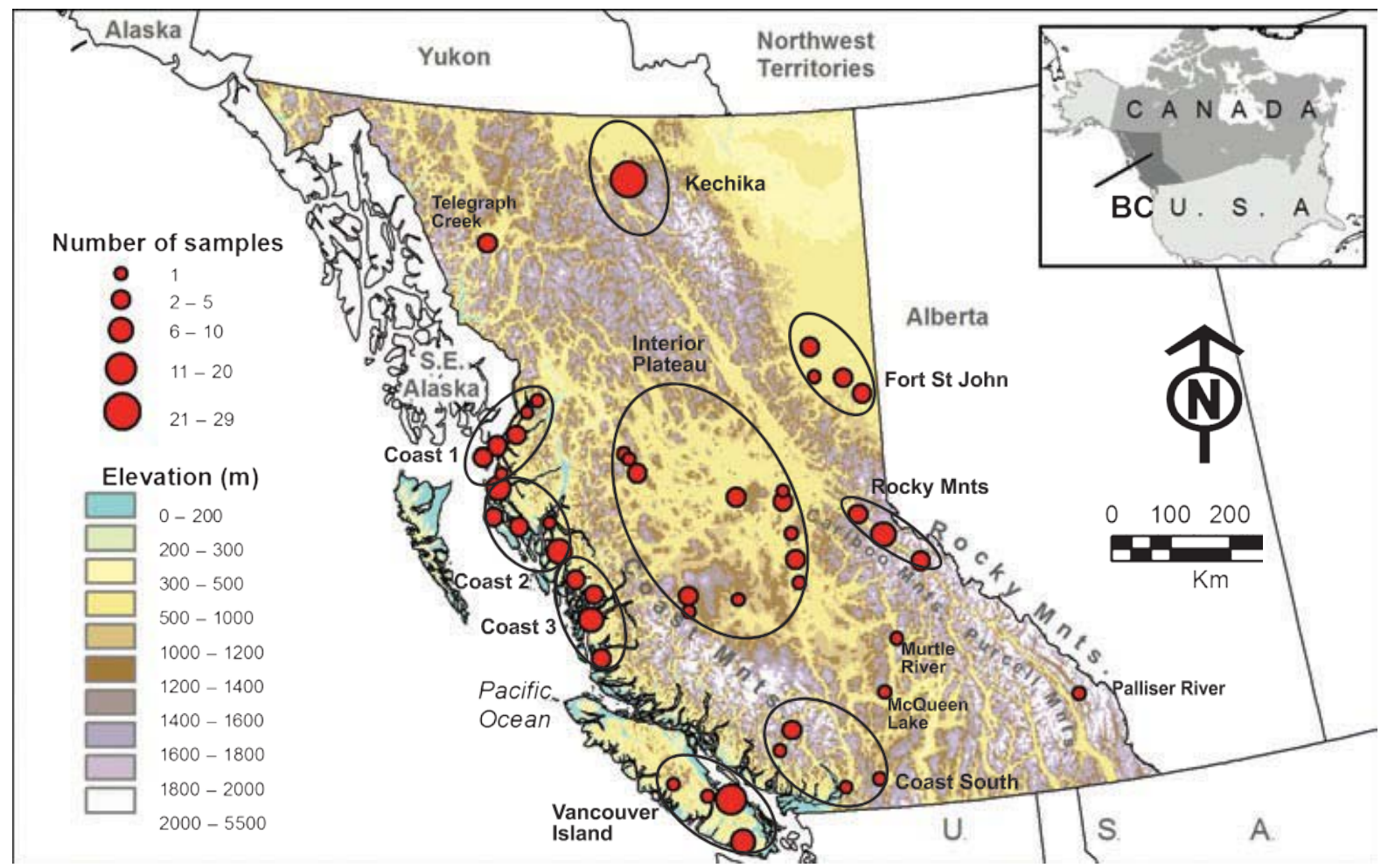

Figure 1 Map of British Columbia showing the elevation and distribution of wolf sampling localities, as indicated by red circles. Ellipses indicate grouping of the sampling localities based on geographical proximity into sampling areas for analyses. Sampling localities in Coast 1, Coast 2, Coast 3, Coast South and Vancouver Island are found in coastal British Columbia, east of the Coast Mountains, and the remaining sampling localities are in inland British Columbia.

Table 1 Geographic coordinates and ecological data for each sampling area. Ungulate composition was entered as common, 2; rare, 1; or absent, 0 .

\begin{tabular}{|c|c|c|c|c|c|c|c|c|c|c|c|}
\hline $\begin{array}{l}\text { Sampling } \\
\text { area }\end{array}$ & Latitude & Longitude & $\begin{array}{l}\text { BGC } \\
\text { zone }\end{array}$ & $\begin{array}{l}\text { Black- } \\
\text { tailed } \\
\text { deer }\end{array}$ & $\begin{array}{l}\text { White- } \\
\text { tailed } \\
\text { deer }\end{array}$ & Elk & Moose & Caribou & Goat & $\begin{array}{l}\text { Big- } \\
\text { horn } \\
\text { sheep }\end{array}$ & $\begin{array}{l}\text { Dall's } \\
\text { sheep }\end{array}$ \\
\hline Vancouver & 49.25 & )124.33 & $\mathrm{CWH}$ & 2 & 0 & 2 & 0 & 0 & 0 & 0 & 0 \\
\hline Coast 1 & 54.92 & )129.98 & $\mathrm{CWH}$ & 2 & 0 & 0 & 1 & 0 & 2 & 0 & 0 \\
\hline Coast 2 & 53.35 & )128.87 & $\mathrm{CWH}$ & 2 & 0 & 0 & 1 & 0 & 2 & 0 & 0 \\
\hline Coast 3 & 52.13 & )128.00 & $\mathrm{CWH}$ & 2 & 0 & 0 & 0 & 0 & 2 & 0 & 0 \\
\hline Coast South & 50.00 & )122.17 & CWH & 2 & 1 & 1 & 2 & 0 & 2 & 0 & 0 \\
\hline Kechika & 59.00 & )127.00 & BWBS & 2 & 2 & 2 & 2 & 2 & 2 & 0 & 2 \\
\hline Fort St John & 56.04 & )121.12 & BWBS & 2 & 2 & 2 & 2 & 2 & 2 & 0 & 2 \\
\hline Interior Plateau & 53.33 & )123.95 & SBS & 2 & 2 & 1 & 2 & 0 & 2 & 0 & 0 \\
\hline Rocky Mountains & 53.01 & )119.50 & SBS & 2 & 2 & 2 & 2 & 2 & 2 & 2 & 0 \\
\hline
\end{tabular}

BGC zone, biogeoclimatic zone; CWH, coastal western hemlock; BWBS, black and white boreal spruce; SBS, sub-boreal spruce.

In order to assess the degree of differentiation, and hence conservation importance, of British Columbia coastal and inland wolves, we obtained mitochondrial DNA (mtDNA) control region sequences for animals from across the province and integrated our genetic results with data on phenotype, behaviour and ecology. MtDNA is an appropriate marker to use to examine the general population structure in wolves because dispersal is not sex-biased (Mech \& Boitani, 2003) and has been shown to correlate with differentiation at nuclear markers in other wolf populations (Pilot et al., 2006; Musiani et al., 2007). We also used these data to test the hypothesis that ecology drives genetic differentiation by assessing the co-variation of distance, habitat and prey composition with genetic differentiation. To place our results in perspective, we also compared the genetic diversity and differentiation of wolves from British Columbia with these measures in other North American populations. 


\section{MATERIALS AND METHODS}

\section{Materials}

A total of 160 wolf mtDNA control region sequences from British Columbia were analysed in this study. Samples included faeces, blood, blood serum, hair, muscle, skin and teeth. Faeces ( $n=43$ ) were collected between 2000 and 2005 across the coastal region in areas we term Coast 1, Coast 2 and Coast 3 in this study (Fig. 1). High-quality samples including blood or blood serum, muscle, skin and hair $(n=46)$ were collected by taxidermists from legally hunted animals and by province officials from animals trapped for reasons other than this study; of these, five were from the coast. Tooth root samples $(n=71)$ from museum specimens collected between 1932 and 1989 were analysed to improve geographical coverage, particularly in interior areas (see Appendix S1 in Supporting Information).

For comparative analyses, samples from adjacent regions were included in this study. DNA from wolves from central Alaska was obtained from muscle samples from the University of Alaska frozen tissue collection ( $n=20$; Appendix S1) and the collection of R. K. Wayne $(n=11)$. Muscle samples from Alberta $(n=10)$ were obtained from the Alberta Environment Natural Resources Service, Canada. DNA from wolves from Inuvik (Northwest Territories) was obtained from the collection of R. K. Wayne $(n=37)$. All sequences from R. K. Wayne's collection and Alberta were previously reported as unpublished data in Leonard et al. (2005). Additional sequences for wolves from these three regions were obtained from the literature (Vilà et al., 1999; Musiani et al., 2007).

\section{Molecular methods}

Faecal samples were handled and extracted in a dedicated faecal DNA laboratory. DNA was extracted using the QIAamp DNA Stool Mini Kit (Qiagen, Hilden, Germany) following the manufacturer's instructions with the addition of a one-hour digestion step. Tooth roots of museum specimens were cut, crushed and extracted in a separate dedicated low-qualityDNA laboratory. DNA extraction was performed following the Yang et al. (1998) protocol involving silica-based spin columns (QIAquick PCR purification kit; Qiagen) with some modifications. Skin, blood, blood serum, hair and muscle samples were digested with proteinase $\mathrm{K}$ overnight at $37^{\circ} \mathrm{C}$, and DNA was extracted using a standard phenol-chloroform extraction (Sambrook et al., 1989).

A 425-base-pair (bp) fragment of the 5t-end of the mtDNA control region was amplified with the primers Thr-L (Vilà et al., 1999) and DLHc (Leonard et al., 2002). DNA was amplified by polymerase chain reaction (PCR) in 25-1L reactions containing 1- Gold Buffer (Applied Biosystems, Foster City, CA, USA), $2.5 \mathrm{~mm} \mathrm{MgCl}_{2}, 1 \mathrm{~mm}$ dNTPs (0.25 mm each), $0.5 \mathrm{Im}$ each primer, 10-100 ng of genomic DNA and $1 \mathrm{U}$ of AmpliTaq Gold DNA polymerase (Applied Biosystems). PCRs were performed in a PTC-225 (MJ Research, Inc., Waltham, MA, USA) thermal cycler with an initial denatur- ation step of $95^{\circ} \mathrm{C}$ for 5 min followed by 45 cycles of $95^{\circ} \mathrm{C}$ for $30 \mathrm{~s}, 55^{\circ} \mathrm{C}$ for $30 \mathrm{~s}$ and $72^{\circ} \mathrm{C}$ for $1 \mathrm{~min}$; and a final extension of $72^{\circ} \mathrm{C}$ for $7 \mathrm{~min}$. PCR negatives were included in all cases to monitor for potential contamination.

Owing to the degraded nature of DNA in most of our samples (faeces and museum material), we included DNA negatives in all extractions that we carried through the PCRs to monitor for potential contamination. To control for errors caused by DNA damage and degradation, we sequenced each faecal and museum sample from at least two independent PCRs. In one sample of faeces and five samples of museum specimens, one or more mismatches were identified. These samples were sequenced from two additional independent PCRs. The consensus sequence, based on identity of all but one sequence, was used in analyses.

PCR products were purified in $18-1 \mathrm{~L}$ reactions containing 15 IL of PCR product, $12 \mathrm{U}$ of Exonuclease I (New England Biolabs, Ipswich, MA, USA) and $1.2 \mathrm{U}$ of Shrimp Alkaline Phosphatase (USB Corporation, Staufen, Germany) incubated at $37^{\circ} \mathrm{C}$ for $15 \mathrm{~min}$ followed by $80^{\circ} \mathrm{C}$ for $15 \mathrm{~min}$. Both strands of each PCR product were sequenced with the same primers as used for amplification, and then reaction products were separated in an automated sequencer (ABI 3730xl DNA Analyzer; Applied Biosystems). Sequences from multiple PCRs were checked and edited using sequencher ver. 4.6 (Gene Codes Corporation, Ann Arbor, MI, USA), and were then aligned by eye using se-al ver. 2.0a11 Carbon (Rambaut, 1996).

In order to reduce the possibility of including multiple faecal samples from the same individual, we used information available as part of another study, consisting of complete and partial genotypes for 30 and four faecal samples, respectively, from coastal British Columbia (Leonard et al., in preparation). These results suggest that re-sampling of the same individual, even in the same locality, is very rare (two identical genotypes were identified twice in 34 samples). Based on these data, in some cases we were able to determine conclusively that multiple samples from the same locality corresponded to different individuals, and so all of these samples were included in our analyses. Otherwise, only one sample per sampling locality, each being typically at least $20 \mathrm{~km}$ from another, was included to reduce the risk of sampling the same individual multiple times. Exclusion of these samples resulted in the inclusion of 43 out of 67 good-quality sequences from faeces and in only one haplotype missed at one locality.

One dog haplotype found in one faecal sample and one sequence found in two faecal samples that showed evidence of being a nuclear insertion (Numt) were excluded from all analyses.

\section{Data analyses}

To illustrate relationships among haplotypes, we constructed an unrooted parsimony network using tcs ver. 1.21 (Clement et al., 2000).

For analyses of structure, samples were grouped based on geographical proximity (Fig. 1): Vancouver Island $(n=22)$, 
Coast $1(n=16)$, Coast $2(n=16)$, Coast $3(n=16)$, Coast South $(n=5)$, Kechika $(n=28)$, Fort St John $(n=11)$, Interior Plateau $(\mathrm{n}=26)$ and Cariboo/Rocky Mountains $(n=14)$. Because samples along the coast were distributed continuously and no geographic or topographic division is evident, we divided the samples into groups of equal size. Six samples were excluded from the British Columbia genetic structure analyses because they could neither be assigned to any group described above owing to the geographic distance separating them from other samples, nor form a group on their own because of their small sample size: Telegraph Creek, $\mathrm{n}=3$, in the north-west, and three samples in the south (Fig. 1). These samples were only included in the larger-scale analyses as part of inland British Columbia.

We used the software samova ver. 1.0 (Dupanloup et al., 2002) to uncover hierarchical groupings of localities and to identify genetic barriers to dispersal. samova determines the most probable genetic structure according to the number of groups entered by the user. We tested for genetic structure with $\mathrm{K}=2$ to $\mathrm{K}=9$ groups. We used 100 annealing processes and repeated the procedure twice to test for consistency. We chose the most probable $\mathrm{K}$ as the one that maximized $\mathrm{U}_{\mathrm{CT}}$ (Dupanloup et al., 2002). To calculate pairwise $U_{S T}$ between the groups we used arlequin ver. 2.001 (Schneider et al., 2000). In both samova and arlequin, the significance of U-statistics and the variance components were assessed using a permutation approach (Excoffier et al., 1992). We controlled for type I error in multiple comparisons using the method of Benjamini \& Hochberg (1995) (also see Verhoeven et al., 2005).

To identify correlations between the genetic distance among the groups (as represented by pairwise $\mathrm{U}_{\mathrm{ST}}$ ) and geographical distance or ecological variables (vegetation cover and prey composition) we used the software distlm ver. 5 and distlm forward ver. 1.3 (Anderson, 2001; McArdle \& Anderson, 2001). Habitat data were entered at two levels: (1) as either coastal or inland, representing the major ecological and environmental differences in British Columbia; and (2) in more detail as biogeoclimatic zone data representing vegetation, soils and climate (temperature and precipitation) (Pojar \& Meidinger, 1991) (see Table 1 for characterization of each sampling area). Prey composition was entered as common, rare or absent for the following ungulates: woodland caribou (Rangifer tarandus caribou), elk (Cervus elaphus), mountain goat (Oreamnos americanus), moose (Alces alces), bighorn sheep (Ovis canadensis), Dall's sheep (Ovis dalli), black-tailed deer and whitetailed deer (Odocoileus virginianus) (Table 1).

Genetic divergence between coastal and inland British Columbia wolves, between these two and other North American populations, and between coastal wolves and two recognized wolf subspecies was measured by calculating pairwise $\mathrm{U}_{\mathrm{ST}}$ between the groups as implemented in arlequin (see above).

\section{RESULTS}

We identified eight distinct haplotypes in 160 wolves from British Columbia (Fig. 2) defined by 11 variable sites in the 425-bp region we sequenced. These variable sites included 10 transitions (C-T, A-G) and one indel. One haplotype in the coastal wolves (lu68) and one in the inland wolves (lu67) had not been previously described. The six remaining haplotypes have been found elsewhere in North America (Vilà et al., 1999; Leonard et al., 2005; Musiani et al., 2007; this paper) (Table 2). The most common haplotype was lu38 (50\% of the individuals analysed).

Within British Columbia, the distribution of haplotypes suggested differentiation between wolves of coastal and interior areas. Haplotype lu68 was absent in inland wolves, and haplotypes lu28, lu29, lu31, lu36 and lu67 were absent in coastal wolves. Only two haplotypes were shared, with lu38 being more common on the coast than inland (76\% and $27 \%$ of the individuals, respectively), and lu32 more common inland than on the coast (36\% and 5\%, respectively) (Table 2). In total, more haplotypes were identified in inland wolves $(n=7)$ than in coastal wolves $(n=3)$, but no endemic haplotypes present at over $2 \%$ were identified in the inland population. Consequently, coastal wolves had lower haplotype diversity $(\mathrm{Hd} \pm \mathrm{SD}=0.390 \pm 0.060)$ than inland wolves $(\mathrm{Hd} \pm \mathrm{SD}=0.749 \pm 0.025)$ and, as a result of all haplotypes being closely related in the coast, coastal wolves also had lower nucleotide diversity ( $\mathrm{p} \pm \mathrm{SD}=0.00096 \pm 0.00016)$ than inland wolves $(\mathrm{p} \pm \mathrm{SD}=0.00641 \pm 0.00057)$. These data suggest that the coastal wolves are more isolated from other wolf populations than the inland wolves are and that their effective population size is smaller.

The relationship among haplotypes was reconstructed using an unrooted parsimony network (Fig. 2). The network clearly shows population structure, with several haplotypes present only in either coastal or inland wolves. The single haplotype endemic to coastal wolves, lu68, is only one base pair different from the widely distributed and most common haplotype, lu38 (Table 2). To represent graphically the haplotype diversity without imposing any grouping, haplotypes were indicated directly on a map (Fig. 3). Figures 2 and 3 both illustrate visually the difference in haplotypes and haplotype frequency between coastal and inland wolves prior to statistical testing, which requires that the samples be grouped.

samova identified structure based on five groups $(K=5)$ as most probable $\left(\mathrm{U}_{\mathrm{CT}}=0.321 ; \mathrm{P}=0.006\right)$ (Table 3): a coastal group, formed by the four coastal sampling areas plus Vancouver Island (Fig. 1), and the four interior sampling areas. For two groups $(K=2)$, the most probable structure identified by SAMOVA was based on a coastal group comprising all sampling areas west of the Coast Mountain range, and an inland group comprising all the remaining sampling areas $\left(\mathrm{U}_{\mathrm{CT}}=0.210 ; \mathrm{P}=0.006\right)$. Between $\mathrm{K}=2$ and $K=5$, the coastal sampling areas remained a unified group, whereas the inland sampling areas, initially grouped together, separated sequentially for each increase of $\mathrm{K}$. The coastal sampling areas divided when $\mathrm{K}$ was greater than the number of inland sampling areas $+1(\mathrm{~K}=6$ and $\mathrm{K}=7)$, but $\mathrm{U}_{\mathrm{CT}}$ then decreased. This suggests that the coastal sampling areas form a cohesive group and that greater genetic differentiation exists 


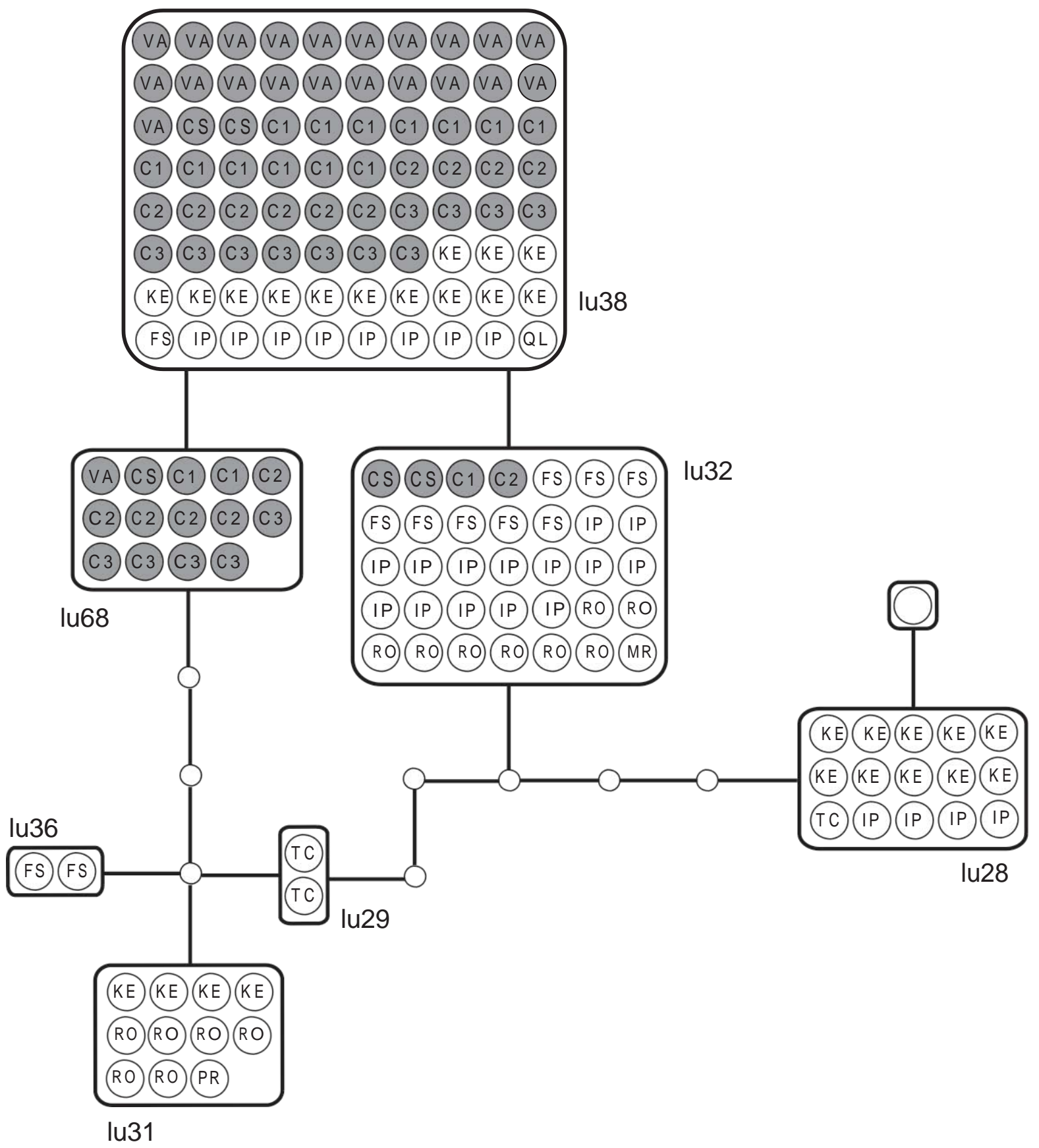

Figure 2 Network of mitochondrial DNA haplotypes identified in British Columbia wolves. Grey indicates a haplotype found in a coastal wolf and white indicates a haplotype found in an inland wolf. Each circle represents an individual, each square a haplotype, and the capital letters stand for the area in which the sample was collected. VA, Vancouver Island; CS, Coast South; C1, Coast 1; C2, Coast 2; C3, Coast 3; KE, Kechika; FS, Fort St John; IP, Interior Plateau; RO, Rocky Mountains; TC, Telegraph Creek; QL, McQueen Lake; PR, Palliser River; MR, Murtle River. Small empty circles represent hypothetical or missing haplotypes, and each bar a one-base-pair change.

among inland than among coastal sampling areas. Because Coast South was represented by only a few samples $(n=5)$, we re-ran samova removing this sampling area from the analysis. The results remained unchanged.

Analysis of pairwise $\mathrm{U}_{\mathrm{ST}}$ between sampling areas (Table 4) indicated that coastal areas were not significantly differentiated from each other (except for Vancouver Island and
Coastal South; $P £ 0.05$ ), whereas genetic differentiation between inland areas ranged from non-significant to highly significant. As in the samova analysis, this result indicates that inland areas are, in general, more differentiated from each other than are coastal localities. Coastal and inland sampling areas were significantly differentiated from each other $\left(U_{S T} \ddagger 0.248, P £ 0.01\right.$ or $\left.P £ 0.001\right)$, except for 
Table 2 Haplotypes identified in wolves from British Columbia and other North American populations used in this study. BC, British Columbia; NWT, Northwest Territories.

\begin{tabular}{|c|c|c|c|c|c|}
\hline Haplotype & Coast BC & Inland BC & Central Alaska & Alberta & Inuvik (NWT) \\
\hline lu11 & & & & & $2^{*}$ \\
\hline lu28 & & 15 & $6+3^{*}+3 \dagger$ & $10 \ddagger+3 *$ & $1^{*}$ \\
\hline lu29 & & 2 & 5 & $1 \ddagger$ & $3^{*}$ \\
\hline lu30 & & & $3+1 *$ & $1 \ddagger$ & \\
\hline lu31 & & 11 & $4^{*}$ & $2 \ddagger$ & $4^{*}$ \\
\hline lu32 & 4 & 31 & $1^{*}$ & $3 \ddagger+7 *$ & $22 *+3 \dagger$ \\
\hline lu35 & & & & $5 \ddagger$ & \\
\hline lu36 & & 2 & & $3 \ddagger$ & \\
\hline lu37 & & & $1+1^{*}$ & & \\
\hline lu38 & 57 & 23 & $2+1^{*}$ & $9 \ddagger$ & $4^{*}$ \\
\hline lu61 & & & 3 & & $1^{*}$ \\
\hline lu67 & & 1 & & & \\
\hline lu68 & 14 & & & & \\
\hline $\mathrm{n}$ & 75 & 85 & 34 & 44 & 40 \\
\hline
\end{tabular}

DDBJ/EMBL/GenBank database accession numbers: FM201598-FM201777.

*Leonard et al. (2005).

†Vilà et al. (1999).

¥Musiani et al. (2007).

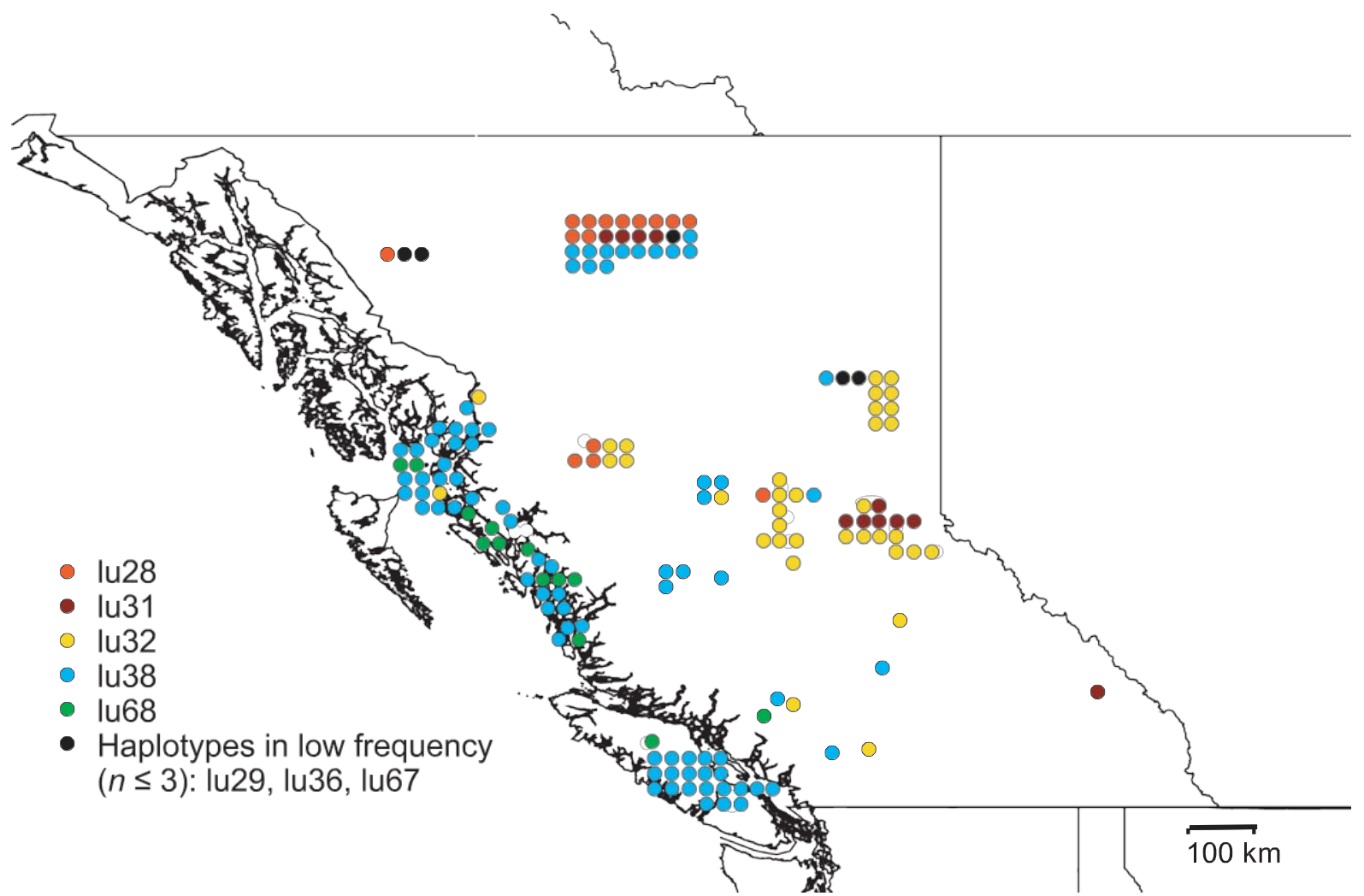

Figure 3 Colour-coded haplotypes of wolves from British Columbia and their distribution across the province.

comparisons involving Coast South. The genetic differentiation of Coast South from any other sampling area was nonsignificant, with the exception of Vancouver Island, probably as a result of a lack of statistical power because of its small sample size $(\mathrm{n}=5)$.
Geographic distance could not explain the greater differentiation between coastal and inland sampling areas (Fig. 4; plotting either $\mathrm{U}_{\mathrm{ST}}$ or the ratio $\mathrm{U}_{\mathrm{ST}} /(1) \mathrm{U}_{\mathrm{ST}}$ ) on the y-axis yielded very similar results). Sampling areas as far apart as Vancouver Island and Coast 1, separated by $770 \mathrm{~km}$, or 
Table 3 Groups of sampling areas identified by samova based on mtDNA data of wolves from British Columbia. *P $£$ 0.05; **P $£ 0.01$; ***P $£ 0.001$. Negative values were converted to zero.

\begin{tabular}{|c|c|c|c|c|}
\hline Number of groups (K) & Group composition & $\mathrm{U}_{\mathrm{sc}}$ & $\mathrm{U}_{\mathrm{ST}}$ & $\mathrm{U}_{\mathrm{CT}}$ \\
\hline 2 & $\begin{array}{l}\text { 1. Van }+\mathrm{Co} 1+\mathrm{Co} 2+\mathrm{Co} 3+\mathrm{CoS} \\
\text { 2. Kechika }+ \text { Interior Plateau }+ \text { Fort St John }+ \text { Rocky Mts }\end{array}$ & $0.135^{* * *}$ & $0.317 * * *$ & $0.210^{* *}$ \\
\hline 3 & $\begin{array}{l}\text { 1. Van }+\mathrm{Co} 1+\mathrm{Co} 2+\mathrm{Co} 3+\mathrm{CoS} \\
\text { 2. Kechika }+ \text { Interior Plateau }+ \text { Fort St John } \\
\text { 3. Rocky Mts }\end{array}$ & $0.085^{* * *}$ & $0.312 * * *$ & $0.248^{* * *}$ \\
\hline 4 & $\begin{array}{l}\text { 1. Van }+ \text { Co } 1+\text { Co } 2+\text { Co3 }+ \text { CoS } \\
\text { 2. Kechika } \\
\text { 3. Interior Plateau + Fort St John } \\
\text { 4. Rocky Mts }\end{array}$ & $0.000 * * *$ & $0.305^{* * *}$ & $0.312^{* * *}$ \\
\hline 5 & $\begin{array}{l}\text { 1. Van }+ \text { Co1 }+ \text { Co2 }+ \text { Co3 }+ \text { CoS } \\
\text { 2. Kechika } \\
\text { 3. Interior Plateau } \\
\text { 4. Fort St John } \\
\text { 5. Rocky Mts }\end{array}$ & $0.000 * * *$ & $0.300 * * *$ & $0.321 * *$ \\
\hline 6 & $\begin{array}{l}\text { 1. Van }+ \text { Co1 }+ \text { Co2 }+ \text { Co3 } \\
\text { 2. CoS } \\
\text { 3. Kechika } \\
\text { 4. Interior Plateau } \\
\text { 5. Fort St John } \\
\text { 6. Rocky Mts }\end{array}$ & $0.000 * * *$ & $0.291 * * *$ & $0.313^{* *}$ \\
\hline 7 & $\begin{array}{l}\text { 1. Co1 }+\mathrm{Co} 2+\mathrm{Co} 3 \\
\text { 2. Van } \\
\text { 3. CoS } \\
\text { 4. Kechika } \\
\text { 5. Interior Plateau } \\
\text { 6. Fort St John } \\
\text { 7. Rocky Mts }\end{array}$ & $0.000 * *$ & $0.266 * * *$ & $0.300^{*}$ \\
\hline
\end{tabular}

Table 4 Pairwise $\mathrm{U}_{\mathrm{ST}}$ values between wolves from regions within British Columbia. Probability values were based on 1023 permutations. Overall $U_{\mathrm{ST}}=0.305, \mathrm{P}<0.0001$. n.s., non-significant; *P $£ 0.05$; **P $£ 0.01 ; * * * P £ 0.001$. Negative values were converted to zero. Significant values remained significant at the 0.05 level after implementing the false discovery rate control of Benjamini \& Hochberg (1995).

Vancouver Island Coast 1 Coast 2 Coast 3 Coast South Kechika Fort St John Interior Plateau Rocky Mountains

Vancouver Island

Coast $1 \quad \overline{0} 000^{\text {n.s. }}$

Coast $2 \quad 0.167^{\text {n.s. }} \quad 0.012^{\text {n.s. }}$ )

Coast $3 \quad 0.192^{\text {n.s. }} \quad 0.032^{\text {n.s. }} 0.000^{\text {n.s. }} \quad-$

Coast South $\quad 0.396^{*} \quad 0.100^{\text {n.s. }} 0.054^{\text {n.s. }} 0.146^{\text {n.s. }}-$

$\begin{array}{llllll}\text { Kechika } & 0.303 * * * & 0.248 * * & 0.248 * * * & 0.262 * * & 0.118^{\text {n.s. }}\end{array}$

$\begin{array}{lllllll}\text { Fort St John } & 0.463^{* * *} & 0.323^{* * *} & 0.298^{* * *} & 0.350^{* * *} & 0.000^{\text {n.s. }} & 0.150^{*}\end{array}$

Interior Plateau $0.383 * * *$

$0.293 * * * \quad 0.311^{* * *} \quad 0.353 * * * 0.031^{\text {n.s. }}$

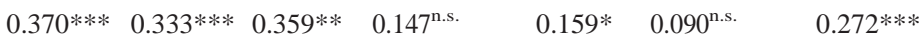

Vancouver Island and Coast 2, separated by $580 \mathrm{~km}$, were not significantly differentiated, whereas Coast 1 and the Interior Plateau, separated by $430 \mathrm{~km}$, or Coast 2 and Interior Plateau, separated by $330 \mathrm{~km}$, were significantly different.

Analyses with distlm tested whether genetic distance between sampling areas was correlated either with geographic distance between them or with differences in habitat or prey composition. A significant positive correlation was found between genetic distance and geographic location (66\% of variation explained, $P=0.039$ ), but when latitude and longi- tude were analysed separately, longitude explained more of the genetic differentiation in the data and was marginally significant (41\% of variation explained, $P=0.047$ ), and latitude had no explanatory value $(P=0.512)$. Vegetation cover, as indexed by biogeoclimatic zone, explained $56 \%$ of the data and was significant $(P=0.016)$. Habitat, entered as coast or interior, explained $65 \%$ of the data $(P=0.014)$. The greatest ecological difference in British Columbia is between coastal and inland areas. This suggests that the association between genetic and geographic distance is the result of the association between 


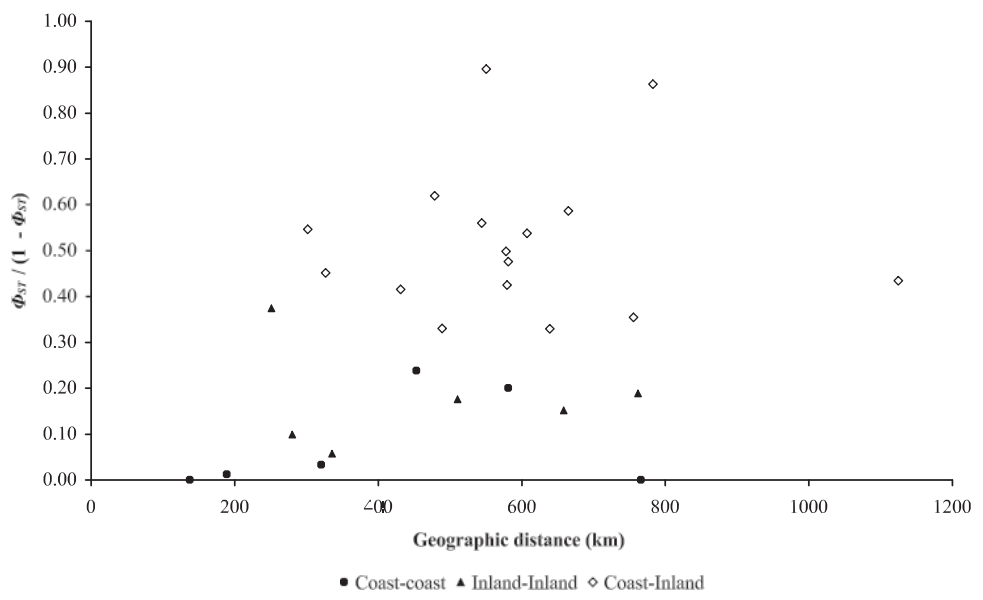

Figure 4 Pairwise $\mathrm{U}_{\mathrm{ST}}$ between groups $(n>5)$ and geographic distance separating them.

habitat and longitude, as well as of that between habitat and genetic differentiation. There was a significant association between the presence of white-tailed deer and moose and genetic distance, with $80 \%(P=0.017)$ and $79 \%(P=0.001)$ of the data explained, respectively. The presence of the remaining ungulates was not significantly correlated with genetic distance (all $\mathrm{P}>0.05$ ). Black-tailed deer was not tested because it was present in all sampling areas. As before, because Coast South was represented by a small sample $(n=5)$, we re-ran distlm after removing this sampling area from the analysis, and the conclusions remained the same. These results strongly suggest that habitat is the major factor determining population structure in British Columbia.

To place our results in a broader geographical context, differentiation between British Columbia wolves and other adjacent populations in North America (Alaska, Alberta and Northwest Territories) was explored. Pairwise $\mathrm{U}_{\mathrm{ST}}$ showed significant differentiation in all cases (Table 5). Coastal wolves were more differentiated than were inland wolves from populations outside British Columbia. Inland wolves shared a large proportion of haplotypes, with some differences in frequency, with wolves from Alaska, Alberta and Northwest Territories, whereas coastal wolves were particularly distinct in haplotype frequency and composition from all others (Table 2). Coastal wolves are the only population to have an endemic haplotype with a frequency greater than 5\% (lu68, 19\%). The most frequent haplotype in coastal wolves, lu38 (77\%), is widespread across North America, but present at much lower frequencies in other populations (i.e. 9\% in central Alaska, $10 \%$ in Inuvik, $20 \%$ in Alberta and $27 \%$ in inland British Columbia).

We also calculated pairwise $U_{S T}$ between coastal wolves and the two currently recognized and geographically adjacent North American wolf subspecies, C. I. occidentalis and C. I. nubilis (as in Nowak, 1995). The subspecies C. I. occidentalis is represented by wolves from Alaska, Alberta and Northwest Territories (Table 2) and C. I. nubilis by historical data (Leonard et al., 2005). All comparisons were significant ( $P<0.00001)$, with coastal British Columbia wolves being more differentiated from C. I. occidentalis $\left(\mathrm{U}_{\mathrm{ST}}=0.305\right)$ and from C. I. nubilis $\left(\mathrm{U}_{\mathrm{ST}}=0.550\right)$ than $\mathrm{C}$. I occidentalis and C. I. nubilis were from each other $\left(\mathrm{U}_{\mathrm{ST}}=0.125\right)$. The genetic differentiation of coastal wolves from other wolves in North America demonstrates that this population is largely isolated. This genetic distinctiveness, in addition to their unique morphology and ecology (Table 6), strongly supports their status as an ESU sensu Crandall et al. (2000).

\section{DISCUSSION}

\section{Ecology and genetic structure of British Columbia wolves}

Dispersal distances of $100 \mathrm{~km}$ are frequent in wolves (Linnell et al., 2005), and dispersal distances over $1000 \mathrm{~km}$ have been observed (Vilà et al., 2003). Although the distance required to

Table 5 Pairwise $\mathrm{U}_{\mathrm{ST}}$ values between wolves from regions across northwest North America. Probability values were based on 1023 permutations. *P $£ 0.05 ; * * P £ 0.01 ; * * * P £ 0.001$. BC, British Columbia; NWT, Northwest Territories. All comparisons remained significant at the 0.05 level after controlling for type I error in multiple comparisons using the false discovery rate method of Benjamini \& Hochberg (1995).

\begin{tabular}{lllll}
\hline & Coast BC & Inland BC & Central Alaska & Alberta \\
\hline Coast BC & - & & & \\
Inland BC & $0.242^{* * *}$ & - & & \\
Central Alaska & $0.574^{* * *}$ & $0.165^{* * *}$ & - & - \\
Alberta & $0.431^{* * *}$ & $0.034^{*}$ & $0.106^{* *}$ & $0.139 * *$ \\
Inuvik (NWT) & $0.411^{* * *}$ & $0.034^{*}$ & $0.250^{* * *}$ & - \\
\hline
\end{tabular}


fulfil two of the criteria sufficient for their designation as an ESU sensu Crandall et al. (2000) (see text).

\begin{tabular}{|c|c|c|}
\hline Criterion & Example & Reference \\
\hline \multirow[t]{3}{*}{ Morphology } & $\begin{array}{l}\text { Pelage: shorter and coarser hair than interior } \\
\text { conspecifics. Grey morph with conspicuous } \\
\text { red tones and brown under-fur common. } \\
\text { Brownish red tinge, a feature responsible for the } \\
\text { one coastal region's historic sub-specific epithet fuscus. }\end{array}$ & $\begin{array}{l}\text { Young \& Goldman (1944); Cowan \& Guiguet (1975); } \\
\text { Wood (1990) }\end{array}$ \\
\hline & Smaller body sizes. & Cowan \& Guiguet (1975); Friis (1985); Wood (1990) \\
\hline & $\begin{array}{l}\text { Cranial morphology; multivariate analyses } \\
\text { identified distinct coastal forms. }\end{array}$ & Friis $(1985)$ \\
\hline \multirow[t]{4}{*}{ Prey specialization } & $\begin{array}{l}\text { Unique prey-based ecotype: wolf-black-tailed deer } \\
\text { system, North America's smallest ungulate. } \\
\text { Other regions include black-tailed deer but } \\
\text { also other ungulates. }\end{array}$ & Darimont et al. (2004); Theberge (1991) \\
\hline & $\begin{array}{l}\text { Evidence for insular predator-prey (wolf-deer) } \\
\text { dynamics on islands. Deer consumed at frequencies } \\
\text { inversely proportional to island isolation. }\end{array}$ & Darimont et al. $(2004,2009)$ \\
\hline & $\begin{array}{l}\text { Populations heavily subsidized by marine resources, } \\
\text { especially in absence of deer; isotopic data } \\
\text { suggest } 25-75 \% \text { of diet is of marine origin } \\
\text { (especially spawning salmon and marine mammals). }\end{array}$ & $\begin{array}{l}\text { Darimont \& Reimchen (2002); Darimont et al. } \\
(2003,2004,2008,2009)\end{array}$ \\
\hline & $\begin{array}{l}\text { Salmon hunting behaviour; high efficiencies and } \\
\text { shared fishing techniques and tissue } \\
\text { targets across coastal region. }\end{array}$ & Darimont et al. (2003) \\
\hline $\begin{array}{l}\text { Other specific } \\
\text { behaviour }\end{array}$ & $\begin{array}{l}\text { Archipelago environment with islands often smaller } \\
\text { than home ranges necessitates frequent } \\
\text { swimming between landmasses. }\end{array}$ & Darimont \& Paquet (2002); Paquet et al. (2006) \\
\hline
\end{tabular}

disperse from the coastal to the inland habitat is well within the range of dispersal distances of North American wolves, our data suggest that gene flow is largely restricted to within coastal and within inland habitats (Figs 2 \& 3, Tables 3-5). This suggests that factors other than distance are responsible for the observed structure.

Geographic barriers do not provide a reasonable explanation for population subdivision among British Columbia wolves either. The Coast Mountain Range, which separates coastal from interior areas of British Columbia, averages only 200 km in width, and there are several large drainages that bisect the range, such as the Stikine, Taku, Kitimat and Skeena, that could be used by wolves as corridors. The Rocky Mountains in interior British Columbia, where some of the samples originated, have been recognized as a dispersal corridor for wolves (Boyd et al., 1995; Forbes \& Boyd, 1996; Carroll et al., 2004) and are similar in average altitude and width to the Coast Mountain Range. For these reasons, it is unlikely that the Coast Mountain Range accounts for the strong phylogeographic structure we identify in British Columbia wolves. Factors other than geography, such as behaviour, wolf-prey dynamics or natural selection, must therefore be driving the genetic differentiation of British Columbia wolves.

Vegetation cover explained $56 \%$ of the data and was highly significant $(P=0.016)$, and so it is an important factor in explaining the pattern of genetic differentiation observed. We also found a significant correlation between genetic differen- tiation and prey, namely white-tailed deer and moose. Both species were absent from our coastal sampling areas (except for moose present in Coast South) and present in all of our inland sampling areas. None of the prey we tested was distributed only on the coast. However, coastal wolves, especially those on islands, can obtain $50 \%$ to $75 \%$ of their protein from marine sources, including salmon and marine mammals (Darimont et al., 2008). Salmon are consumed to a lesser extent and in fewer areas in interior regions, probably owing to reduced availability (Darimont \& Reimchen, 2002). Habitat, defined as coast or interior, explained $65 \%$ of the data $(P=0.014)$. Therefore, habitat appears to be the most likely driving factor for the observed differentiation.

Recent analyses of other grey wolf populations with detailed sampling have identified population structure within continents related to climate and vegetation across a west-east axis in North America (Geffen et al., 2004), to hunting specialization on migratory caribou versus non-migratory prey in the North American Arctic (Carmichael et al., 2001, 2007; Musiani et al., 2007), and to climate, habitat type and diet composition in Eastern Europe (Pilot et al., 2006). In coyotes, natal experience is important in determining where dispersing individuals settle, but overall habitat quality and social cohesion (neighbouring individuals) may be important contributors as well (Sacks et al., 2004, 2005, 2008). Similarly, dispersing wolves in British Columbia may select a territory based on the presence of a particular prey species or, 


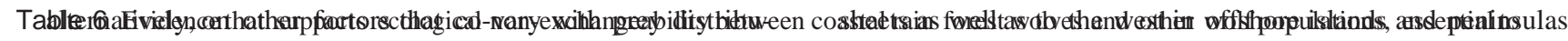

tion. Independent of the availability of particular prey items, habitat structure may be important because it may affect den site selection or the ability to employ learned behaviours. Habitat-biased dispersal may promote divergence between coastal and inland wolves.

A reduction in the fitness of dispersing individuals upon reaching ecologically divergent non-natal habitats may further foster genetic isolation ('selection against immigrants'; Nosil et al., 2005). A dispersing individual with learned behavioural adaptations to a particular habitat would have an advantage over dispersers without such experience. Important behavioural adaptations may include hunting techniques and disease avoidance. A solitary individual may hunt deer, but capturing and dismembering moose generally requires coordination among several individuals. For example, an interior-born wolf that disperses into coastal areas could forage on salmon, but may be more prone to suffering acute symptoms of salmonpoisoning disease (Neorickettsia helminthoeca), as the consumption of salmon tissue types high in parasitic load can be fatal to canids, including wolves (Philip, 1955; Knapp \& Millemann, 1970). Coastal wolves consume primarily the head of captured salmon (Darimont et al., 2003), foregoing the nutritionally valuable body presumably to avoid Neorickettsia concentrated in the viscera (Bennington \& Pratt, 1960; Baldwin et al., 1967). Marine mammals, too, are a known reservoir of viral diseases to terrestrial mammals (Prato et al., 1974), which could provide novel challenges to wolves migrating from the interior to the coast.

\section{Evolutionary origin of British Columbia wolves}

On a larger geographic scale, all comparisons of genetic differentiation between coastal British Columbia wolves, inland British Columbia wolves and wolves from adjacent areas (Alaska, Alberta and Northwest Territories) were significant. The differentiation between coastal and inland wolves was similar to or greater than the divergence between inland wolves and other more distant populations of wolves in North America (Table 5), which highlights the genetic distinctiveness of the coastal wolves. Differences between wolves from Alaska, Alberta, Northwest Territories and inland British Columbia were the result mostly of differences in frequency of some widely distributed haplotypes that were shared by all populations. In contrast, coastal wolves were differentiated by a combination of highly divergent frequencies in shared haplotypes and an endemic haplotype (lu68) present in 19\% of coastal individuals (Table 2). The endemic coastal haplotype (lu68) differs from a common and widespread haplotype (lu38) by a single mutation. This close relationship and its uniqueness suggest that this haplotype evolved in the coastal wolf population after this population was isolated from others.

During the Last Glacial Maximum, the Canadian Pacific Northwest was almost completely covered by the Cordilleran ice-sheet (Clark et al., 1993). Some animal and plant taxa survived in refugia north (now Alaska) and south of the ice-
(Alexander Archipelago, Queen Charlotte Islands or Haida Gwaii) (e.g. Heaton et al., 1996; Cook et al., 2006). As the ice retreated, many organisms re-colonized coastal and interior British Columbia/Alaska from different refugia, which left an imprint in current patterns of genetic diversity (e.g. long-tailed vole Microtus longicaudus, Conroy \& Cook, 2000; ermine Mustela erminea, Fleming \& Cook, 2002; martens Martes sp., Small et al., 2003; deermice Peromyscus sp., Zheng et al., 2003; lichen Lobaria pulmonaria, Walser et al., 2005; moose Alces alces, Hundertmark et al., 2006; lodgepole pine Pinus contorta, Godbout et al., 2008; mountain sorrel Oxyria digyna, Marr et al., 2008). So far, no suitable refugium for wolves has been found in the west, and it has previously been shown that the wolf population in Ice Age Alaska went extinct at the end of the Pleistocene and was not ancestral to any living population (Leonard et al., 2007). Furthermore, in wolves from British Columbia we observed high-frequency haplotypes that have a continent-wide distribution and closely related endemic haplotypes. Consequently, these results support an origin from a single refugium.

The distribution of common shared haplotypes across all northern North American populations is consistent with the hypothesis that wolves re-colonized Canada and Alaska, including the Pacific Northwest, from south of the ice-sheets after the Cordilleran glacier receded, probably following the northern expansion of deer less than 10000 years ago (Klein, 1965; Cook et al., 2006; Leonard et al., 2007). This suggests that the strong differentiation between coastal wolves and other North American wolf populations evolved in the Holocene.

Post-Pleistocene colonization of previously glaciated areas has left a signature of population differentiation in several species (Hewitt, 2000; and references above). However, given the biology and ecology of the grey wolf, history alone cannot explain the observed population structure on this scale because (1) there is little or no sex-biased dispersal in wolves in North America (Merrill \& Mech, 2000; Linnell et al., 2005), (2) the distance between the habitats is small in comparison to the dispersal capability of wolves (Fritts, 1983; Merrill \& Mech, 2000; Linnell et al., 2005), and (3) wolves are easily capable of crossing all terrain between the two habitats (Forbes \& Boyd, 1996). Therefore, it is necessary to consider alternative explanations for the cause of the observed pattern.

Using nuclear microsatellite data, Weckworth et al. (2005) identified a similar discontinuity between south-eastern coastal and interior Alaskan wolves. This may suggest that the distinct population we identify in coastal British Columbia extends north through the south-eastern coast and islands of Alaska.

\section{Evolutionary distinctiveness of coastal wolves}

Recently, efforts have been made to standardize the application of units below the species level. The designations management unit (MU) and evolutionarily significant unit (ESU) have been proposed with a series of testable criteria (Moritz, 1994; 
Crandall et al., 2000). The criteria of Moritz (1994) depend entirely on genetic differentiation, defined as reciprocal monophyly at mitochondrial markers and significant divergence at nuclear loci. This definition prioritizes evolutionary heritage over adaptive divergence. By the definitions of Moritz, the coastal wolves constitute a management unit (MU), because they have significantly different frequencies of mtDNA alleles, but are not reciprocally monophyletic, and nuclear divergence has not been tested.

Crandall et al. (2000) give weight to both historical isolation and adaptive distinctiveness. They developed a classification in which four null hypotheses of exchangeability must be tested. The four hypotheses are recent and historical genetic and ecological exchangeability. The rejection patterns of those hypotheses lead to different management actions. In the case of the coastal wolves, two of the three criteria Crandall et al. (2000) suggested were used to reject the hypotheses of current and historic genetic exchangeability: the observation of a unique allele (lu68) and low gene-flow estimates ( $\mathrm{Nm}<1$, approximately when $F_{\mathrm{ST}}=0.2$ ). Crandall et al. (2000) recommended testing the hypotheses regarding ecological exchangeability by overlaying ecological data on the underlying genealogy of the population. We have done this by employing a method for non-parametric multivariate analysis of variance (Anderson, 2001), which has been developed since Crandall et al. (2000) published their recommendations but applies very well to these data. These tests showed a significant correlation between genetic diversity and ecological factors. In addition, rejection of the hypotheses of ecological exchangeability is further strengthened by aspects of the coastal wolves' biology and ecology, including a unique diet heavily influenced by marine resources, distinct behaviours such as swimming in the open ocean between landmasses, and their darker colour, smaller size and cranial and dental morphology (Table 6). Therefore, the null hypotheses of recent and historic genetic and ecological exchangeability can be rejected for the coastal wolves, and hence they should be classified as an ESU sensu Crandall et al. (2000).

Another definable, sub-specific unit is the designatable unit (DU) (Green, 2005). This unit avoids a judgement of evolutionary importance, and is designed to be the basic unit within species. The genetic and biogeographical distinctiveness of coastal British Columbia wolves each independently qualifies them as a DU. This terminology is of particular relevance in the context of British Columbia wolves because it has been accepted by the Committee on the Status of Endangered Wildlife in Canada (Green, 2005).

Subspecies of grey wolves have been described based on morphological characteristics (Young \& Goldman, 1944; Hall, 1981; Nowak, 1995). Of the 24 subspecies across North America recognized by Hall (1981), three coastal subspecies were identified: Canis lupus ligoni in south-east Alaska, C. I. fuscus in coastal British Columbia, Washington and Oregon (now only extant in British Columbia), and C. I. crassodon on Vancouver Island. The most recent revision of North American wolf taxonomy reduced the 24 previously recognized North American subspecies to five and pooled all coastal wolves into the subspecies C. I. nubilus, which includes wolves from most of the conterminous United States and eastern Canada, including the Hudson Bay area (Nowak, 1995). Notably, wolves from coastal British Columbia were not included in the accompanying morphological analyses (Nowak, 1995). In our study, we found that the level of genetic differentiation between wolves of coastal British Columbia and subspecies in North America (sensu Nowak, 1995) was greater than that between subspecies. Future taxonomic work involving a detailed morphological analysis of coastal wolves in comparison with wolves from elsewhere in North America, reconciled with genetic data, would be informative on the subspecies issue. Although no type specimen was designated, the subspecies fuscus was the first used for coastal wolves (Richardson, 1839) and therefore has precedence over the other two subspecies designations.

\section{Conservation implications}

Coastal wolves are an isolated population uniquely adapted to the temperate rain forests of North America's north-west coast. These forests once stretched from California to southern Alaska (Schoonmaker et al., 1997), but more than half have been severely altered by clear-cut logging and other human activities, especially in California, Oregon and Washington, where wolves were extirpated (Jeo et al., 1999). Wolves of coastal rain forests are now restricted to British Columbia and south-east Alaska. Of the remaining coastal wolves, those in British Columbia occupy some of the most pristine wolf habitat remaining on Earth and have enjoyed relative freedom from persecution by humans. However, the future of this remnant population is not clear. Coastal wolves from southeast Alaska are threatened by extensive timber removal, which has been predicted to cause a decline in deer and, consequently, wolf populations (Person et al., 1996). Direct overharvesting could also become a problem as their habitat becomes more accessible to hunters via logging roads (Kirchhoff, 1991; USDA Forest Service, 1991; Person \& Ingle, 1995; Person et al., 1996). Another anthropogenic threat to these wolves comes in the form of domestic dogs, through their ability to spread canid diseases and potentially hybridize with wolves (Vilà et al., 2003). Both protection of the Pacific temperate rain forest and mitigation of these threats are needed for the long-term conservation of coastal wolves.

The results presented here illustrate how habitat differences drive and maintain genetic differentiation in the grey wolf. The observation of this pattern in an ecosystem generalist with great dispersal capabilities suggests that ecological factors may drive genetic differentiation in other species as well. Even in cases without obvious phenotypic adaptations, populations of one species living in different habitats may represent distinct subsets of the total genetic diversity. Conservation programmes thus should aim to encompass as much ecological diversity as possible to preserve species-wide genetic diversity and evolutionary potential. 


\section{ACKNOWLEDGEMENTS}

Randy Kadatz and Curtis English from the Alberta Environment Natural Resources Service, Canada, assisted in sample collection. Adrian Walton of the British Columbia Ministry of Forests provided the biogeoclimatic data. We thank Helen Schwantje of the BC Ministry of Environment, Rex Kenner from the University of British Columbia Cowan Vertebrate Museum, Jim Cosgrove from the Royal British Columbia Museum, and the University of Alaska for access to samples in collections. We thank Katrina Bennett for her invaluable assistance with map production and Carles Vilà for his critical reading of the manuscript. Logistical support was provided by the Center for Conservation \& Evolutionary Genetics, National Zoological Park, Smithsonian Institution, USA. Funding was provided by the Carl Trygger Foundation, the National Geographic Society, Patagonia, the Spanish Ministry of Education, the Swedish Research Council, the US National Science Foundation, the Wilburforce Foundation and the World Wildlife Fund Canada. We thank the Raincoast Conservation Foundation for initiating and supporting the Rainforest Wolf Project, as well as for funding a portion of this work. Field sampling occurred in the Traditional Territories of several First Nation groups, from whom we obtained permission before research began. In particular, we thank the Heiltsuk Nation, which has been a project partner since inception.

\section{REFERENCES}

Anderson, M.J. (2001) A new method for non-parametric multivariate analysis of variance. Austral Ecology, 26, 32-46.

Avise, J., Arnold, J., Ball, R., Bermingham, E., Lamb, T., Neigel, J., Reeb, C. \& Saunders, N. (1987) Intraspecific phylogeography: the mitochondrial DNA bridge between population genetics and systematics. Annual Review of Ecology and Sytematics, 18, 489-522.

Baldwin, N., Millemann, R. \& Knapp, S. (1967) Salmon poisoning disease III. Effect of experimental Nanophyetus salmincola infection on the fish host. Journal of Parasitology, 53, 556-564.

Benjamini, Y. \& Hochberg, Y. (1995) Controlling the false discovery rate: a practical and powerful approach to multiple testing. Journal of the Royal Statistical Society B, 57, 289-300.

Bennington, E. \& Pratt, I. (1960) The life history of the salmon-poisoning fluke, Nanophyetus salmincola (Chapin). Journal of Parasitology, 46, 91-100.

Bolnick, D.I., Svanback, R., Fordyce, J.A., Yang, L.H., Davis, J.M., Hulsey, C.D. \& Forister, M.L. (2003) The ecology of individuals: incidence and implications of individual specialization. The American Naturalist, 161, 1-28.

Boyd, D., Paquet, P., Donelon, S., Ream, R., Pletscher, D. \& White, C. (1995) Transboundary movements of a recolonizing wolf population in the Rocky Mountains. Ecology and conservation of wolves in a changing world (ed. by L. Carbyn, S. Fritts and D. Seip), pp. 135-140. Canadian Circumpolar Institute, Edmonton, Canada.
Carmichael, L.E., Nagy, J.A., Larter, N.C. \& Strobeck, C. (2001) Prey specialization may influence patterns of gene flow in wolves of the Canadian northwest. Molecular Ecology, 10, 2787-2798.

Carmichael, L.E., Krizan, J., Nagy, J.A., Fuglei, E., Dumond, M., Johnson, D., Veitch, A., Berteaux, D. \& Strobeck, C. (2007) Historical and ecological determinants of genetic structure in Arctic canids. Molecular Ecology, 16, 3466-3483.

Carroll, C., Noss, R., Paquet, P. \& Schumaker, N. (2004) Extinction debt of protected areas in developing landscapes. Conservation Biology, 18, 1110-1120.

Clark, P.U., Clague, J.J., Curry, B.B., Dreimanis, A., Hicock, S.R., Miller, G.H., Berger, G.W., Eyles, N., Lamothe, M., Miller, B.B., Mott, R.J., Oldale, R.N., Stea, R.R., Szabo, J.P., Thorleifson, L.H. \& Vincent, J.S. (1993) Initiation and development of the Laurentide and Cordilleran ice sheets following the last interglaciation. Quaternary Science Reviews, 12, 79-114.

Clement, M., Posada, D. \& Crandall, K.A. (2000) TCS: a computer program to estimate gene genealogies. Molecular Ecology, 9, 1657-1660.

Conroy, C.J. \& Cook, J.A. (2000) Phylogeography of a postglacial colonizer: Microtus longicaudus (Rodentia: Muridae). Molecular Ecology, 9, 165-175.

Cook, J.A., Bidlack, A.L., Conroy, C.J., Demboski, J.R., Fleming, M.A., Runck, A.M., Stone, K.D. \& MacDonald, S.O. (2001) A phylogeographic perspective on endemism in the Alexander archipelago of southeast Alaska. Biological Conservation, 97, 215-227.

Cook, J.A., Dawson, N.G. \& MacDonald, S.O. (2006) Conservation of highly fragmented systems: the north temperate Alexander archipelago. Biological Conservation, 133, 1-15.

Cowan, I.M. \& Guiguet, C.J. (1975) The mammals of British Columbia. British Columbia Provincial Museum Handbook No. 11. British Columbia Provincial Museum, Victoria, Canada.

Crandall, K.A., Bininda-Edmonds, O.R.P., Mace, G.M. \& Wayne, R.K. (2000) Considering evolutionary processes in conservation biology. Trends in Ecology and Evolution, 15, 290-295.

Dalén, L., Fuglei, E., Hersteinsson, P., Kapel, C.M.O., Roth, J.D., Samelius, G., Tannerfeldt, M. \& Angerbjorn, A. (2005) Population history and genetic structure of a circumpolar species: the arctic fox. Biological Journal of the Linnean Society, 84, 79-89.

Darimont, C.T. \& Paquet, P.C. (2002) The gray wolves, Canis lupus, of British Columbia's central and north coast: distribution and conservation assessment. Canadian Field Naturalist, 116, 416-422.

Darimont, C.T. \& Reimchen, T.E. (2002) Intra-hair stable isotope analysis implies seasonal shift to salmon in gray wolf diet. Canadian Journal of Zoology, 80, 1638-1642.

Darimont, C.T., Reimchen, T.E. \& Paquet, P.C. (2003) Foraging behaviour by gray wolves on salmon streams in coastal British Columbia. Canadian Journal of Zoology, 81, 349-353. 
Darimont, C.T., Price, M.H.H., Winchester, N.N., GordonWalker, J. \& Paquet, P.C. (2004) Predators in natural fragments: foraging ecology of wolves in British Columbia's central and north coast archipelago. Journal of Biogeography, 31, 1867-1877.

Darimont, C.T., Paquet, P.C. \& Reimchen, T.E. (2007) Stable isotopic niche predicts fitness of prey in a wolf-deer system. Biological Journal of the Linnean Society, 90, 125-137.

Darimont, C.T., Paquet, P.C. \& Reimchen, T.E. (2008) Spawning salmon disrupt tight trophic coupling between wolves and ungulate prey in coastal British Columbia. BMC Ecology, 8, 14.

Darimont, C.T., Paquet, P.C. \& Reimchen, T.E. (2009) Landscape heterogeneity and marine subsidy generate extensive niche variation in a terrestrial carnivore. Journal of Animal Ecology, 79, 126-133.

Doebeli, M. \& Dieckmann, U. (2003) Speciation along environmental gradients. Nature, 421, 259-264.

Dupanloup, I., Schneider, S. \& Excoffier, L. (2002) A simulated annealing approach to define the genetic structure of populations. Molecular Ecology, 11, 2571-2581.

Excoffier, L., Smouse, P.E. \& Quattro, J.M. (1992) Analysis of molecular variance inferred from metric distances among DNA haplotypes: application to human mitochondrial DNA restriction data. Genetics, 131, 479-491.

Fleming, M.A. \& Cook, J.A. (2002) Phylogeography of endemic ermine (Mustela erminea) in southeast Alaska. Molecular Ecology, 11, 795-807.

Forbes, S.H. \& Boyd, D.K. (1996) Genetic variation of naturally colonizing wolves in the central Rocky Mountains. Conservation Biology, 10, 1082-1090.

Fraser, D.J. \& Bernatchez, L. (2001) Adaptive evolutionary conservation: towards a unified concept for defining conservation units. Molecular Ecology, 10, 2741-2752.

Friis, L.K. (1985) An investigation of subspecific relationships of the grey wolf, Canis lupus, in British Columbia. MSc Thesis, University of Victoria, Victoria, Canada.

Fritts, S.H. (1983) Record dispersal of a wolf from Minnesota. Journal of Mammology, 64, 166-167.

Funk, D.J., Nosil, P. \& Etges, W.J. (2006) Ecological divergence exhibits consistently positive associations with reproductive isolation across disparate taxa. Proceedings of the National Academy of Sciences USA, 103, 3209-3213.

Geffen, E., Anderson, M.J. \& Wayne, R.K. (2004) Climate and habitat barriers to dispersal in the highly mobile grey wolf. Molecular Ecology, 13, 2481-2490.

Godbout, J., Fazekas, A., Newton, C.H., Yeh, F.C. \& Bousquet, J. (2008) Glacial vicariance in the Pacific Northwest: evidence from a lodgepole pine mitochondrial DNA minisatellite for multiple genetically distinct and widely separated refugia. Molecular Ecology, 17, 2463-2475.

Green, D.M. (2005) Designatable units for status assessment of endangered species. Conservation Biology, 19, 1813-1820.

Hall, E.R. (1981) The mammals of North America, 2nd edn. John Wiley and Sons, New York.
Heaton, T.H., Talbot, S.L. \& Shields, G.F. (1996) An ice age refugium for large mammals in the Alexander archipelago, southeastern Alaska. Quaternary Research, 46, 186-192.

Hewitt, G. (2000) The genetic legacy of the Quaternary Ice Ages. Nature, 405, 907-913.

Hoekstra, H., Krenz, J. \& Nachman, M. (2005) Local adaptation in the rock pocket mouse (Chaetodipus intermedius): natural selection and phylogenetic history of populations. Heredity, 94, 217-228.

Hoelzel, A.R., Dahlheim, M. \& Stern, S.J. (1998) Low genetic variation among killer whales (Orcinus orca) in the eastern north Pacific and genetic differentiation between foraging specialists. Journal of Heredity, 89, 121-128.

Hundertmark, K.J., Bowyer, R.T., Shields, G.F., Schwartz, C.C. \& Smith, M.H. (2006) Colonization history and taxonomy of moose Alces alces in southeastern Alaska inferred from mtDNA variation. Wildlife Biology, 12, 331-338.

Jeo, R.M., Sanjayan, M.A. \& Sizemore, D. (1999) A conservation area design for the central coast region of British Columbia, Canada. Round River Conservation Studies, Salt Lake City, UT.

Kirchhoff, M.D. (1991) Status, biology and conservation concerns for the wolf (Canis lupus ligoni) in southeast Alaska. Unpublished Management Report. Alaska Department of Fish and Game, Juneau, AK.

Klein, D.R. (1965) Postglacial distribution patterns of mammals in the southern coastal regions of Alaska. Arctic, 10, 7-20.

Knapp, S.E. \& Millemann, R.E. (1970) Salmon poisoning disease. Infectious diseases of wild mammals (ed. by J.H. Davis, L.H. Karstad and D.O. Trainer), pp. 332-342. Iowa State University Press, Ames, IA.

Lehman, N., Eisenhawer, A., Hansen, K., Mech, L.D., Peterson, R.O., Gogan, P.J.P. \& Wayne, R.K. (1991) Introgression of coyote mitochondrial DNA into sympatric North American gray wolf populations. Evolution, 45, 104-119.

Leonard, J.A., Wayne, R.K., Wheeler, J., Valádez, R., Guillén, S. \& Vilà, C. (2002) Ancient DNA evidence for Old World origin of New World dogs. Science, 298, 1613-1616.

Leonard, J.A., Vilà, C. \& Wayne, R.K. (2005) Legacy lost: genetic variability and population size of extirpated US gray wolves (Canis lupus). Molecular Ecology, 14, 9-17.

Leonard, J.A., Vilà, C., Fox-Dobbs, K., Koch, P.L., Wayne, R.K. \& Van Valkenburg, B. (2007) Megafaunal extinctions and the disappearance of a specialized wolf ecomorph. Current Biology, 17, 1146-1150.

Linnell, J.D.C., Brøseth, H., Solberg, E.J. \& Bainerd, S.M. (2005) The origins of the southern Scandinavian wolf Canis lupus population: potential for natural immigration in relation to dispersal distances, geography and Baltic ice. Wildlife Biology, 11, 383-391.

Marr, K.L., Allen, G.A. \& Hebda, R.J. (2008) Refugia in the cordilleran ice sheet of western North America: chloroplast DNA diversity in the arctic-alpine plant Oxyria digyna. Journal of Biogeography, 35, 1323-1334. 
McArdle, B.H. \& Anderson, M.J. (2001) Fitting multivariate models to community data: a comment on distance-based redundancy analysis. Ecology, 82, 290-297.

McRae, B.H., Beier, P., Dewald, L.E., Huynh, L.Y. \& Keim, P. (2005) Habitat barriers limit gene flow and illuminate historical events in a wide-ranging carnivore, the American puma. Molecular Ecology, 14, 1965-1977.

Mech, L. \& Boitani, L. (2003) Wolf social ecology. Wolves: behaviour, ecology and conservation (ed. by L. Mech and L. Boitani), pp. 1-34. University of Chicago Press, Chicago.

Merrill, S.B. \& Mech, L.D. (2000) Details of extensive movements by Minnesota wolves (Canis lupus). American Midland Naturalist, 144, 428-433.

Moritz, C. (1994) Defining “Evolutionary significant units”' for conservation. Trends in Ecology and Evolution, 9, 373-375.

Musiani, M., Leonard, J.A., Cluff, H.D., Gates, C.C., Mariani, S., Paquet, P.C., Vilà, C. \& Wayne, R.K. (2007) Differentiation of tundra and boreal coniferous forest wolves: genetics, coat color and foraging ecology. Molecular Ecology, 16, 4149-4170.

Nagorsen, D.W. (1990) The mammals of British Columbia: a taxonomic catalogue. Memoir number 4. Royal British Columbia Museum, Victoria, Canada.

Nosil, P., Vines, T.H. \& Funk, D.J. (2005) Perspective: reproductive isolation caused by natural selection against immigrants from divergent habitats. Evolution, 59, 705-719.

Nowak, R.M. (1995) Another look at wolf taxonomy. Ecology and conservation of wolves in a changing world (ed. by L.N. Carbyn, S.H. Fritts and D.R. Seip), pp. 375-398. Canadian Circumpolar Institute, Edmonton, Canada.

Paquet, P.C., Darimont, C.T., Moola, F.M. \& Genovali, C. (2004-2005) Connectivity where the land meets the sea; preserving the last of the best. Wild Earth, 14, 21-25.

Paquet, P.C., Alexander, S.M., Swan, P.L. \& Darimont, C.T. (2006) The influence of natural landscape fragmentation and resource availability on connectivity and distribution of marine gray wolf (Canis lupus) populations on the Central Coast, British Columbia, Canada. Connectivity conservation (ed. by K. Crooks and M.A.E. Sanjayan), pp. 130-156. Society for Conservation Biology, Cambridge University Press, Cambridge.

Person, D.K. \& Ingle, M.A. (1995) Ecology of the Alexander Archipelago wolf and responses to habitat change. Progress Report Number 3. Alaska Department of Fish and Game, Douglas, AK.

Person, D.K., Kirchhoff, M., Van Ballenberghe, V., Iverson, G.C. \& Grossman, E. (1996) The Alexander Archipelago wolf: a conservation assessment. General Technical Report PNWGTR-384. United States Department of Agriculture, Forest Service, Pacific Northwest Research Station, Portland, OR.

Philip, C.B. (1955) There's always something new under the "parasitological"' sun (the unique story of helminth-borne salmon poisoning disease). Journal of Parasitology, 41, 125148.

Pilot, M., Jedrzejewski, W., Branicki, W., Sidorovich, V.E., Jedrzejewska, B., Stachura, K. \& Funk, S.M. (2006)
Ecological factors influence population genetic structure of European grey wolves. Molecular Ecology, 15, 4533-4553.

Pojar, J. \& Meidinger, D. (1991) British Columbia: the environmental setting. Ecosystems of British Columbia, Special Report Series 6 (ed. by D. Meidinger and J. Pojar), pp. 39-68. British Columbia Ministry of Forests, Victoria, Canada. Available at: http://www.for.gov.bc.ca/hfd/pubs/Docs/Srs/ Srs06.htm (last accessed 2 October 2008).

Prato, C.M., Akers, T.G. \& Smith, A.W. (1974) Serological evidence for calicivirus transmission between marine and terrestrial mammals. Nature, 246, 255-256.

Rambaut, A. (1996) Se-Al: Sequence alignment editor. Department of Zoology, University of Oxford, Oxford.

Richardson, J. (1839) The zoology of Captain Beechey's voyage compiled from the collections and notes made by Captain Beechey, the officers and naturalist of the expedition, during a voyage to the Pacific and Behring's Straits performed in his Majesty's Ship Blossom 1825-28. Henry G. Bohn, London.

Rueness, E.K., Jorde, P.E., Hellborg, L., Stenseth, N.C., Ellegren, H. \& Jakobsen, K.S. (2003a) Cryptic population structure in a large, mobile mammalian predator: the Scandinavian lynx. Molecular Ecology, 12, 2623-2633.

Rueness, E.K., Stenseth, N.C., O’Donoghue, M., Boutin, S., Ellegren, H. \& Jakobsen, K.S. (2003b) Ecological and genetic spatial structuring in the Canadian lynx. Nature, 425, 69-72.

Ryder, O.A. (1986) Species conservation and systematics - the dilemma of subspecies. Trends in Ecology and Evolution, 1, 9-10.

Sacks, B.N., Brown, S.K. \& Ernest, H.B. (2004) Population structure of California coyotes corresponds to habitatspecific breaks and illuminates species history. Molecular Ecology, 13, 1265-1275.

Sacks, B.N., Mitchell, B.R., Williams, C.L. \& Ernest, H.B. (2005) Coyote movements and social structure along a cryptic population genetic subdivision. Molecular Ecology, 14, 1241-1249.

Sacks, B.N., Bannasch, D.L., Chomel, B.B. \& Ernest, H.B. (2008) Coyotes demonstrate how habitat specialization by individuals of a generalist species can diversify populations in a heterogeneous ecoregion. Molecular Biology and Evolution, 25, 1384-1394.

Sambrook, E., Fritsch, F. \& Maniatis, T. (1989) Molecular cloning. Cold Spring Harbor Press, Cold Spring Harbor, NY.

Schneider, S., Roessli, D. \& Excoffier, L. (2000) ARLEQUIN ver. 2.000: a software for population genetics data analysis. Genetics and Biometry Laboratory, University of Geneva, Switzerland. Available at: http://lgb.unige.ch/arlequin/ (last accessed 2 October 2008).

Schoonmaker, P.K., Von Hagen, B. \& Wolf, E.C.E. (1997) The rainforests of home: profile of a North American bioregion. Island Press, Washington, DC.

Shackleton, D. (1999) Hoofed mammals of British Columbia. University of British Columbia Press, Vancouver, Canada.

Sharma, D.K., Maldonado, J.E., Jhala, Y.V. \& Fleischer, R.C. (2003) Ancient wolf lineages in India. Proceedings of the Royal Society B: Biological Sciences, 271, S1-S4. 
Small, M.P., Stone, K.D. \& Cook, J.A. (2003) American marten (Martes americana) in the Pacific Northwest: population differentiation across a landscape fragmented in time and space. Molecular Ecology, 12, 89-103.

Theberge, J.B. (1991) Ecological classification, status and management of the gray wolf, Canis lupus, in Canada. Canadian Field Naturalist, 105, 459-463.

USDA Forest Service (1991) Supplement to the draft environmental impact statement. Tongass national forest land management plan revision. R10-MB-149. USDA Forest Service, Juneau, AK.

Verhoeven, K.J.F., Simonsen, K.L. \& McIntyre, L.M. (2005) Implementing false discovery rate control: increasing your power. Oikos, 108, 643-647.

Vilà, C., Amorim, I.R., Leonard, J.A., Posada, D., Castroviejo, J., Petrucci-Fonseca, F., Crandall, K.A., Ellegren, H. \& Wayne, R.K. (1999) Mitochondrial DNA phylogeography and population history of the grey wolf Canis lupus. Molecular Ecology, 8, 2089-2103.

Vilà, C., Sundqvist, A.-K., Flagstad, Ø., Seddon, J., Björnerfeldt, S., Kojola, I., Casulli, A., Sand, H., Wabakken, P. \& Ellegren, H. (2003) Rescue of a severely bottlenecked wolf (Canis lupus) population by a single immigrant. Proceedings of the Royal Society B: Biological Sciences, 270, 91-97.

Walser, J.C., Holderegger, R., Gugerli, F., Hoebee, S.E. \& Scheidegger, C. (2005) Microsatellites reveal regional population differentiation and isolation in Lobaria pulmonaria, an epiphytic lichen. Molecular Ecology, 14, 457-467.

Wayne, R.K., Lehman, N., Allard, N.W. \& Honeycutt, R.L. (1992) Mitochondrial DNA variability of the grey wolf: genetic consequences of population decline and habitat fragmentation. Conservation Biology, 6, 559-569.

Weckworth, B.V., Talbot, S., Sage, G.K., Person, D.K. \& Cook, J. (2005) A signal for independent coastal and continental histories among North American wolves. Molecular Ecology, 14, 917-931.

Wood, R.E. (1990) Game management in unit 1A. Alaska Department of Fish and Game; federal aid in wildlife restoration; annual report of survey-inventory activities; project W-23-2; study 12.0 (ed. by S.O. Morgan). Government of Alaska, Juneau, AK.

Yang, D.Y., Eng, B., Waye, J.S. \& Saunders, S.R. (1998) Technical note: improved DNA extraction from ancient bones using silica-based spin columns. American Journal of Physical Anthropology, 105, 539-543.
Young, S.P. \& Goldman, E.A. (1944) The wolves of North America. Dover Publications Inc., New York.

Zheng, X.G., Arbogast, B.S. \& Kenagy, G.J. (2003) Historical demography and genetic structure of sister species: deermice (Peromyscus) in the North American temperate rain forest. Molecular Ecology, 12, 711-724.

\section{SUPPORTING INFORMATION}

Additional Supporting Information may be found in the online version of this article:

Appendix S1 Museum samples of wolves from Alaska and British Columbia used in this study.

Please note: Wiley-Blackwell is not responsible for the content or functionality of any supporting materials supplied by the authors. Any queries (other than missing material) should be directed to the corresponding author for the article.

\section{BIOSKETCHES}

Violeta Muñ oz-Fuentes is interested in conservation and evolutionary biology and applies molecular biology techniques to answer questions about the ecology and evolution of species.

Chris Darimont is interested in marine influences on terrestrial predator-prey systems and spatial ecology, as well as in the role of predation risk in maintaining intra-population variability in foraging behaviour of prey.

Robert Wayne applies molecular genetic techniques to study questions in population genetics, systematics, genomics and conservation genetics of vertebrates.

Paul Paquet is interested in the research and conservation of large carnivores and contributes to projects around the world.

Jennifer Leonard applies genetic techniques to determine how and why populations are structured through time and space, and which factors drive some populations to extinction or expansion.

Editor: Brett Riddle 